\title{
TINGKAH LAKU MAKAN, KAWIN, MENYUSUI DAN MENYUSU KELELAWAR PEMAKAN BUAH (Pteropus alecto) DI PENANGKARAN/ EX-SITU
}

\author{
Nurul Sapika, T.A. Ransaleleh*, H.J. Kiroh, M.J. Nangoy
}

Fakultas Peternakan, Universitas Sam Ratulangi Manado, 95115

\begin{abstract}
ABSTRAK
Tujuan penelitian ini yaitu mempelajari beberapa tingkah laku kelelawar pemakan buah Pteropus alecto khususnya yang dipelihara di penangkaran (ex-situ). Materi yang digunakan terdiri dari 4 ekor kelelawar jantan dewasa, 5 ekor kelelawar betina dewasa, yang menyusui dan 5 ekor anak sedang tahap menyusui dengan menggunakan metode kuantitatif dengan pengambilan data survei tingkah laku menggunakan metode desktiptif. Variabel yang diukur dalam penelitian yaitu frekuensi dan lamanya dalam melakukan tingkah laku makan, kawin, menyusui dan menyusu. Hasil yang diperoleh diuraikan sebagai berikut: a. tingkah laku makan harian berfrekuensi rata-rata $4,12 \mathrm{kali} / \mathrm{jam}$ dan lamanya ratarata 3,78 menit/jam, b. tingkah laku harian kawin berfrekuensi 0,57 kali/jam dan lamanya rata-rata 0,31 menit/jam c. frekuensi tingkah laku harian menyusui rata-rata $0,84 \mathrm{kali} / \mathrm{jam}$ dan lamanya ratarata 2,16 menit/jam d. tingkah laku harian menyusu berfrekuensi rata-rata 0,69 kali/jam dan lamanya rata-rata 2,20 menit/jam. Berdasarkan hasil penelitian dapat disimpulkan frekuensi dan lamanya setiap tingkah laku yang ditunjukkan oleh kelelawar secara berurutan dari paling sering dan lama adalah makan, menyusui, menyusu dan kawin.
\end{abstract}

*Korespondensi (Corresponding author):

Email: taransaleleh@unsrat.ac.id
Kata Kunci: Kelelawar Pteropus alecto, ex-situ, Tingkah laku

\begin{abstract}
EATING, BREASTFEEDING, MATING, BREALING BEHAVIOR OF FRUIT EATING BATS IN EX-SITU /CAPTIVITY. The aim of this study was to understanding about behavior of the frugivores Pteropus alecto especially in ex-situ (captivity). Four adult male bats, 5 adult female bats, and 5 young bats were used in this study. The variable in this study is frequency and duration when doing eating behavior, mate behavior, breastfeeding behavior, and suckling behavior. The result of this study as follows; Eating behavior frequency in a hour 4.12 and duration in minute/hour 3.78 ; Mate behavior in a hour 0.57 and duration minute/hour 0.31; Breastfeeding average frequency in a hour 0.84 and duration minute/hour 2.16; Suckling frequency in a hour 0.69 and duration minute/hour 2.20. Based on the result it can be concluded that the most frequency and duration by sequence is eating, mating, breastfeeding and suckling behavior.
\end{abstract}

Keywords: Bats (Pteropus alecto), Ex-situ Captive, Behavior. 


\section{PENDAHULUAN}

Sebagian masyarakat Sulawesi

Utara, khususnya masyarakat Minahasa memiliki kebiasaan mengonsumsi daging satwa liar seperti kelelawar. Saat ini eksploitasi kelelawar di habitat asli meningkat seiring dengan permintaan daging kelelawar yang tinggi di pasar tradisional (Ruba et al., 2018). Hal ini mengancam jumlah populasi kelelawar di alam (Ransaleleh et al., 2013; Ransaleleh, 2016). Diperlukan upaya untuk mempertahankan jumlah populasi kelelawar tersebut dengan cara penetapan kouta penangkapan di habitat asli dan pengembangan budidayanya melalui penangkaran. Keberhasilan penangkaran sangat ditentukan oleh keterampilan penangkaran dalam menangani satwa (Lane et al., 2006). Penanganan satwa di penangkaran harus mengikuti tingkah laku satwa seperti cara makan, kawin, menyusui dan menyusu. Pada umumnya publikasi tentang biologi kelelawar sudah banyak dilaporkan sedangkan tingkah laku di habitat aslinya dan di penangkaran ex situ masih kurang. Oleh karena itu telah dilakukan penelitian tingkah laku makan, kawin, menyusui, dan menyusu kelelawar Pteropus alecto di penangkaran ex-situ untuk mendapatkan informasi tingkah laku dalam menunjang keberhasilan penangkaran kelelawar. Penelitian ini telah dilaksanakan dengan tujuan untuk mempelajari beberapa tingkah laku kelelawar pemakan buah Pteropus alecto di penangkaran ex situ.

\section{MATERI DAN METODE PENELITIAN}

Penelitian ini dilaksanakan di penangakaran milik Kel. Polii Ransaleleh Kecematan Wanea, Kota Manado selama 30 hari. Penelitian ini menggunakan 9 ekor dewasa kelelawar jenis Pteropus alecto yang terdiri dari 4 ekor kelelawar jantan dewasa, 5 ekor kelelawar betina dewasa yang menyusui dan 5 ekor anak sedang tahap menyusui. Kandang yang digunakan pada penelitian ini berbentuk rumah dengan ukuran tingginya $\pm 2,5 \mathrm{~m}$, lebar $1 \mathrm{~m}$ dan panjangnya $\pm 2 \mathrm{~m}$ yang dilengkapi tempat makan dan minum. Peralatan yang digunakan pada penelitian ini adalah kamera, alat tulis menulis Termomether dan Stopwatch. Metode penelitian yang digunakan adalah metode penelitian survei terhadap tingkah laku dan pengambilan data secara deskriptif terhadap berbagai tingklah laku yang dipelihara dan di kandang secara berkelompok. 


\section{Prosedur Penelitian}

Pengamatan dilakukan setiap hari, dimulai dari pukul 18.00 sampai 24.00 selama 30 hari. Pengamatan dilakukan dengan mengamati langsung dan mencatat semua tingkah laku makan, tingkah laku kawin, tingkah laku menyusui dan menyusu dari kelelawar menggunakan tabel ethogram sedangkan data tentang frekuensi dan lamanya menggunakan tingkah laku menggunakan kertas di lembar kerja.

\section{Variabel Penelitian}

Tingkah laku makan. Frekuensi makan diperoleh dari berapa kali mengambil makanan perjam selama waktu pengamatan dari pukul 18.00- 24.00 Wita. Lamanya makan diperoleh dari berapa menit kelelawar jantan dan betina mengambil makanan perjam selama waktu pengamatan dari pukul 18.00-24.00 Wita.

Tingkah laku kawin. Frekuensi kawin diperoleh dari berapa kali kelelawar jantan dan betina melakukan aktivitas kawin perjam selama waktu pengamatan dari pukul 18.0024 .00 Wita. Lamanya kawin diperoleh dari berapa menit kelelawar jantan dan betina melakukan aktivitas kawin perjam selama waktu pengamatan dari pukul 18.00-24.00 Wita.

\section{Tingkah laku menyusui.}

Frekuensi menyusui diperoleh dari berapa kali menyusui perjam selama waktu pengamatan dari pukul 18.00-24.00 Wita. Lamanya menyusui diperoleh dari berapa menit menyusui perjam selama waktu pengamatan dari pukul 18.00-24.00 Wita.

Tingkah laku menyusu. Frekuensi menyusu diperoleh dari berapa kali menyusu perjam selama waktu pengamatan dari pukul 18.00-24.00 Wita. Lamanya menyusu diperoleh dari berapa menit menyusui perjam selama waktu pengamatan dari pukul 18.00-24.00 Wita.

\section{Analisa Data}

Data dikumpulkan dan dihitung secara deskriptif terhadap semua variabel yang diamati.

\section{HASIL DAN PEMBAHASAN}

\section{Tingkah Laku Makan}

Tingkah laku kelelawar pemakan buah Pteropus alecto yang terlihat pada buah-buah yang diberikan selama pengambilan data, dan secara perlahan merayap dengan kedua tungkai depan diletakkan pada dinding kawat yang ada dalam kandang, kemudian mengambil potongan-potongan buah, dengan mulut. Buah-buahan yang telah diperoleh dipegang dengan satu kakinya, sambil kaki yang satu memegang jeruji- jeruji kawat yang ada di dalam kandang, dan sayapnya dibuka sedikit dengan posisi bertengger. 

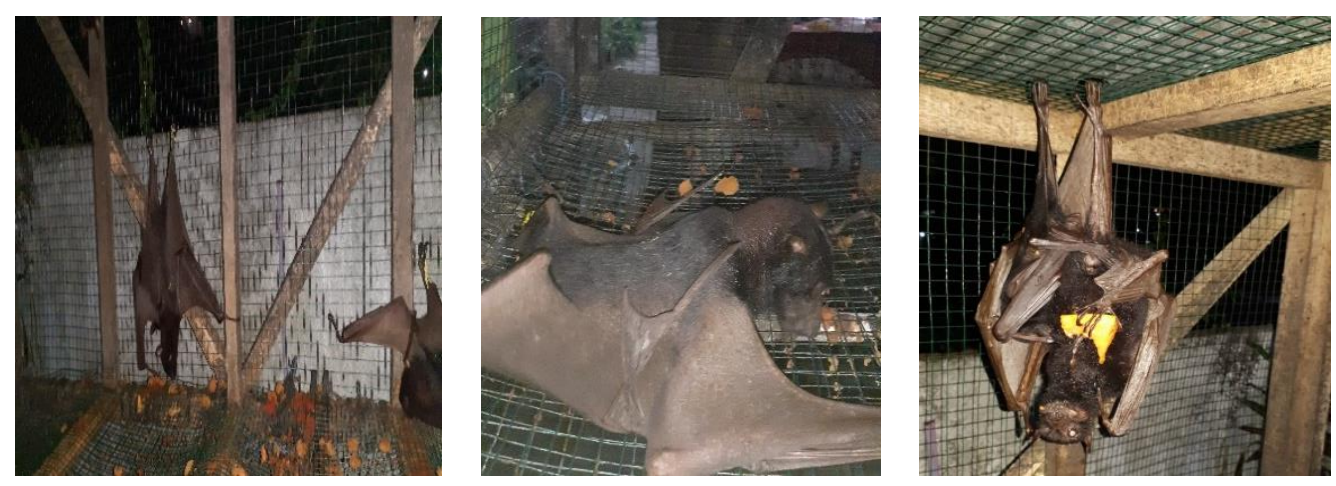

Gambar 1. Tingkah laku makan

Selanjutnya mengunyah-ngunyah buahbuahan untuk mengambil sari-sari buahnya dan melepaskan atau menyisihkan ampasampas buah yang tidak dimanfaatkan lagi (Gambar 1). Hasil pengamatan terhadap tingkah laku makan pada penelitian di penangkaran tidak jauh berbeda dengan tingkah laku kelelawar di alam yang dilaporkan oleh Eisentraut (1952) dan Gopakumar et al. (1998) yaitu merangkak, turun pohon, dan mengambil makanan. Aktivitas lain yang teramati saat melakukan tingkah laku berkelahi, menggigit, grooming.

\section{Tingkah Laku Kawin}

Tingkah laku kawin kelelawar pemakan buah Pteropus alecto yang teramati selama penelitian adalah, kelelawar jantan ereksi, kemudian mendekati, mengejar dan menggigit bagian leher kelelawar betina lalu menjilati sayap dan bagian ventral kelelawar betina (Gambar 2). Tingkah laku kawin banyak
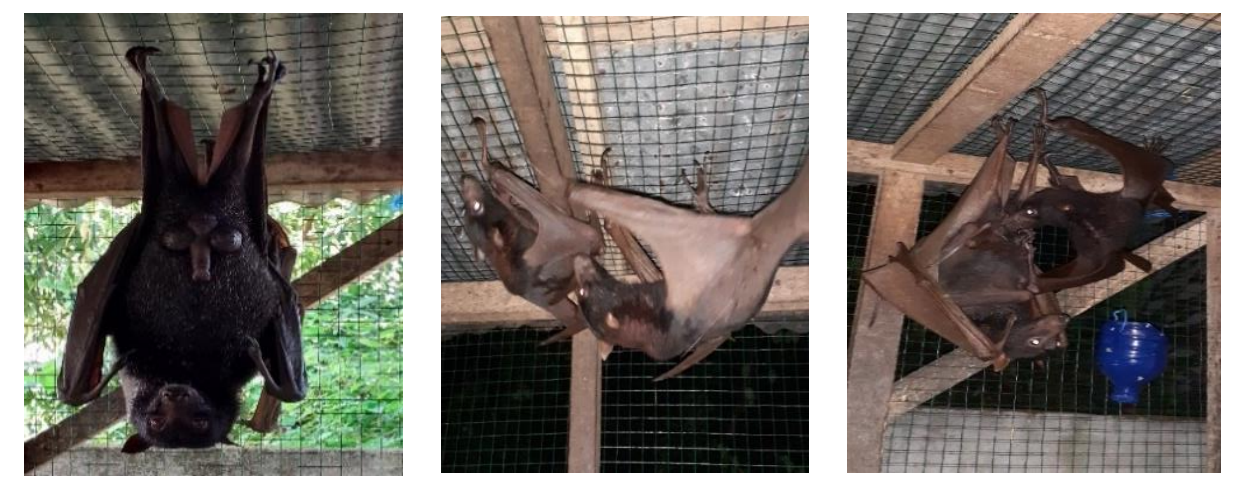

Gambar 2. Tingkah laku kawin 
dilakukan pada sore dan malam hari dan kurang pada pagi hari, karena pada pagi hari kelelawar tidur dengan membungkus seluruh tubuhnya dengan sayap. Hasil penelitian ini tidak berbeda dengan tingkah laku kawin kelelawar di alam. Markus dan Blackshaw (2002) melaporkan bahwa tingkah laku kelelawar Pteropus alecto jantan saat kawin memperlihatkan kejantanannya yaitu alat kelaminnya ereksi, kemudian mengejar sambil mengeluarkan suara dan menjilat bagian ventral betina. Tingkah laku kelelawar jantan saat ingin kawin, mengelilingi kandang sampai membesarkan scrotumnya lalu mengeluarkan penis dan keluar cairan, kemudian berulang-ulang menjilati penisnya dan mendekati kelelawar betina dengan cara mengaitkan satu tungkainya ke badan kelelawar betina, merangkul dari belakang, menggigit bagian leher. Kelelawar jantan dan betina menyusui mengeluarkan suara-suara khas, sehingga kopulasi terjadi. Campbell (1996) melaporkan bahwa ciri-ciri kelelawar jantan pada saat kawin adalah adalah sering mengeluarkan suara yang nyaring.

\section{Tingkah Laku Menyusui}

Tingkah laku menyusui kelelawar pemakan buah Pteropus alecto yang terlihat selama pengambilan data yaitu memperlihatkan gerakan-gerakan seperti induk mengangguk-anggukkan kepalanya, sayap dibentangkan pada posisi bertengger dan menjilat-jilat seluruh tubuh bagian anak. Bayi kelelawar selalu digendong pada bagian ventral tubuh dengan posisi kepala ke bawah saat anak menyusui (Gambar 3).
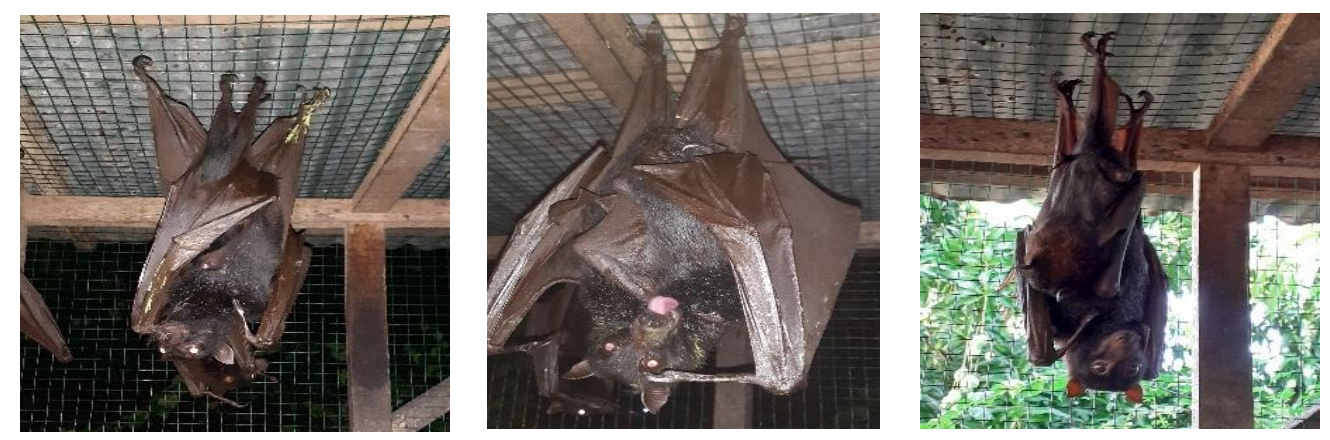

Gambar 3. Tingkah laku menyusui 

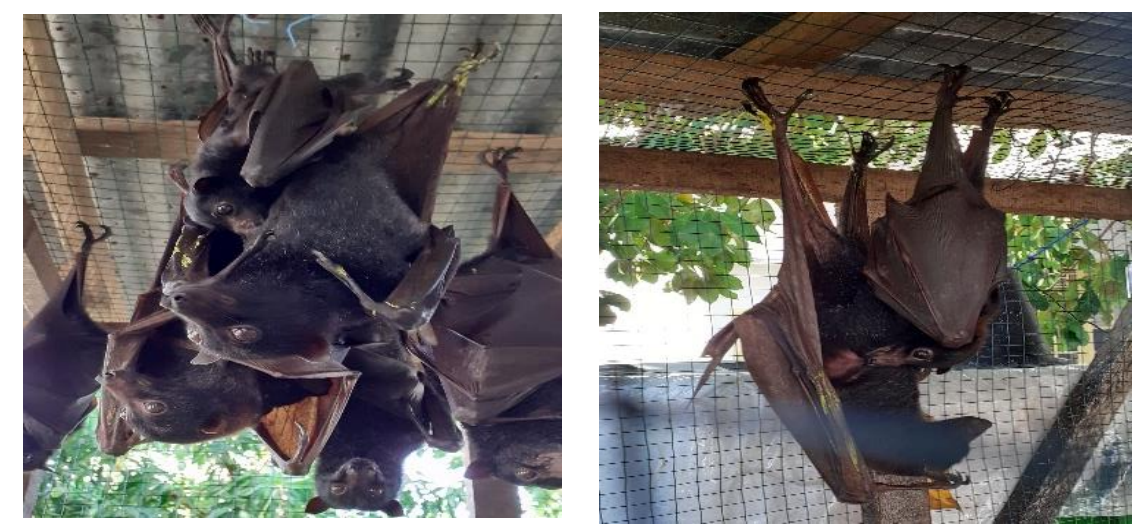

Gambar 4. Tingkah laku menyusu

\section{Tingkah Laku Menyusu}

Tingkah laku menyusu selama pengambilan data yaitu anak kelelawar merangkul tubuh induk dengan sayapnya pada posisi dibawah putting induk, kedua kakinya meerkat pada bagian dada induk sambal mulut dimasukkan keputing induk. Tingkah laku lainnya yang terlihat selama menyusui, kakinya tidak merangkul induknya melainkan bertengger dikawat, induknya sambal mulutnya pada putting menyusui (Gambar 4).

\section{Frekwensi dan Lamanya Tingkah laku kelelawar di Penangkaran}

Tabel 1 menunjukkan bahwa total rataan frekuensi makan sebesar 4,12 kali/jam dan total rataan lamanya makan sebesar 3,78 menit/jam. Besarnya nilainilai persentase yang diperlihatkan oleh kelelawar buah Pteropus alecto baik frekuensi makan yang ditunjukkan dalam kandang penangkaran ex-situ tidak jauh berbeda yang ditunjukkan di alam bebas. Menurut Alikodra (1990) menyatakan

Tabel 1. Rataan Frekuensi dan Lamanya Tingkah Laku Kelelawar di Penangkaran ( ex situ)

\begin{tabular}{lcc}
\hline Tingkah laku & $\begin{array}{c}\text { Frekuensi } \\
(\text { Kali/jam })\end{array}$ & $\begin{array}{c}\text { Lamanya } \\
(\text { Menit/Jam })\end{array}$ \\
\hline Makan & 4,12 & 3,78 \\
Kawin & 0,57 & 0,31 \\
Menyusui & 0,84 & 2,16 \\
Menyusu & 0,69 & 2,20 \\
\hline
\end{tabular}


bahwa persentase kelelawar buah di dalam memakan beberapa jenis buah seperti buah mangga, pepaya, dan pisang sebesar 40,23\% dan lama tingkah laku makan sebesar $50,12 \%$.

Frekuensi kawin pada penelitian ini sebesar 0,57 kali/jam dan lamanya kawin sebesar 0,31 menit/jam. Hal ini disebabkan karena pada saat pengamatan induk betina masih sedang menyusui anaknya. Hasil pengamatan yang diperoleh dalam penelitian ini tidak beda jauh dengan tingkah laku kawin yang ada di habitat aslinya (in situ) dan habitat luar (ex-situ). Markus dan Blackshaw (2002) melaporkan bahwa musim kawin kelelawar pemakan buah Pteropus alecto terjadi pada bulan (Februari-April) dan kelahiran pada bulan (Agustus-November). Sedangkan Connell et al. (2006) melaporkan bahwa musim kawin kelelawar Pteropus poliecephalus di alam bulan April sampai awal Juni. Selanjutnya frekuensi menyusui sebesar 0,84 kali/jam dan lamanya menyusui sebesar 2,16 menit/kali. Besaran nilai frekuensi menyusui dan lamanya menyusui kelelawar yang ditunjukkan dalam kandang penangkaran (ex-situ), dalam penelitian ini terlihat tidak jauh berbeda yang ditunjukkan di alam bebas. Menurut Syamsi (2013) gambaran menyusui antara lain, posisi ini memudahkan anak untuk menemukan putting susu saat haus atau lapar. Tubuh bayi secara keseluruhan selalu diselimuti dengan sayap induk dan hanya beberapa kali dibiarkan keluar dari tutupan sayap induk, yaitu saat grooming, belajar berjalan dan sesekali pada saat menyusui. Saat berada dalam tutupan sayap induk, anak biasanya tidur dan istirahat sambil menyusu kepada induk. Kemudian selanjutnya bahwa frekuensi menyusu sebesar 0,69 kali/hari dan lamanya menyusu sebesar 2,20 menit/hari. Besaran nilai frekuensi menyusu dan lamanya menyusu kelelawar yang ditunjukkan dalam kandang penangkaran ex-situ, dalam penelitian ini terlihat tidak jauh berbeda seperti disampaikan oleh Syamsi, (2013) melaporkan dimana ketika bayi (anak) menyusu yang sering dilakukan antara lain tubuh bayi secara keseluruhan selalu diselimuti dengan sayap induk dan hanya beberapa kali dibiarkan keluar dari tutupan sayap induk, yaitu saat grooming, belajar berjalan dan sesekali pada saat menyusu.

\section{KESIMPULAN}

Berdasarkan hasil penelitian dapat disimpulkan frekuensi dan lamanya setiap tingkah laku yang ditunjukkan oleh kelelawar secara berurutan dari paling sering dan lama adalah makan, menyusui, menyusu dan kawin. 


\section{DAFTAR PUSTAKA}

Alikodra, 1990. Pengelolaan Satwa Liar. IPB Bogor.

Campbell, LA., J.G. Hallet, dan O'Connel, MA. 1996. Conservation of bats in managed forest: use of roost by brown bats. eptesicus fuscus, conform to the fission- fusion model. Journal Animal Behaviour. 68(3): 495-505.

Connell, K.A., U. Munro, dan F.R. Torpy. 2006. Daytime behaviour of the grey-headed flying fox Pteropus poliocephalus Temminck (Pteropodidae: Megachiroptera) at an autumn/winter roost. Journal Australian Mammalogy 28: 7-14.

Eisentraut, M. 1952. Beobach tungen uber jajdroute un flugbeginn bei fledermausen. Bonn. Zool. Beitr. 3: 211-220.

Gopakumar, N., N.V. Elangovan and R. Subburaj. 1998. Effect of moonlight on foraging behavior of Indian short-nosed fruit bats Cynopterus sphinx: Study of radio telemetry. Curr. Sci. 74(8): 688-689.

Lane, D.J.W., T. Kingston, Lee B.P.Y-H. 2006. Dramatic decline in bat species richness in Singapore, with implication for Southeast Asia. Journal Biol Conserv. 131:584-593.

Markus, N. dan J. D. Blackshaw. 2002. Behaviour of the black flying fox Pteropus alecto: An ethogram of behaviour, and preliminary characterisation of mother-infant interactions. Apta Chiroptelorogica 4(2): 137-152.

Ransaleleh, T.A., R.R.A. Maheswari, P. Sugita, W. Manalu, 2013. Identifikasi kelelawar pemakan buah asal Sulawesi berdasarkan morfometri. Jurnal Veteriner 14(4): 485-494.

Ransaleleh, T.A. 2016. Komposisi Kimia Daging segar dan sifat organoleptik kelelawar olahan. Jurnal Zootek 36 (2): $447-465$.

Ruba, E., T.A. Ransaleleh, D.B.J. Rumondor. 2018. Sifat organoleptik daging kelelawar dengan waktu pemasakan yang berbeda. Zootec 38(2): $278-285$

Syamsi, F. 2013. Tingkah Laku Siang Hari Cynopterus sphinx (Vahl,1797). Simbiosa 2(1): 1-1 